\title{
Divergence in hybrid rice parental lines detected by RAPD and ISSR markers
}

\author{
Ghaffar KIANI* and Camellia KATALANI
}

Received February 03, 2018; accepted June 19, 2018.

Delo je prispelo 03. februarja 2018, sprejeto 19. junija 2018.

\begin{abstract}
Genetic distance between parental lines used in hybrid rice breeding program was estimated based on information from molecular markers data. Sixteen parents (5 CMS, 5 maintainers and 6 restorers) were analyzed with 15 random amplification polymorphic DNA (RAPD) and 20 inter simple sequence repeat (ISSR) marker. Out of 15 RAPD markers, 9 were polymorphic and 79 bands were generated, of which 28 bands were polymorphic ( $35 \%$ ). By using 10 out of 20 ISSR markers 86 bands were detected, of which 35 bands were polymorphic $(41 \%)$. Marker index $(\mathrm{RAPD}=1.68$; ISSR $=$ 1.88 ) and percent of polymorphic bands indicated that ISSR markers were relatively more efficient in polymorphism detection. Cluster analysis of the parents based on Jaccard's genetic similarity and UPGMA method were revealed 3 groups. Restorer lines IR68061 and IR5931 with origin of the Philippines were found in distinct group. Results suggesting the cross between CMS lines Neda and Nemat with restorer lines IR68061 and IR5931, can be used as the best heterotic groups for exploration of heterosis.
\end{abstract}

Key words: rice; restorer; maintainer; cluster analysis; molecular marker

\section{IZVLEČEK}

\section{LOČEVANJE HIBRIDNIH STARŠEVSKIH LINIJ RIŽA Z RAPD IN ISSR MARKERJI}

Genetska oddaljenost med starševskimi linijami riža, ki so bile uporabljene $\mathrm{v}$ programu vzgoje hibridnega riža, je bila ocenjena na osnovi informacij iz podatkov, pridobljenih $\mathrm{z}$ molekularnimi markerji. Šestnajst staršev (5 CMS, 5 vzdrževalnih linij (vzdrževalci) in 6 linij, ki povrnejo fertilnost (obnovitelji) je bilo analiziranih s 15 RAPD in 20 ISSR markerji. Med 15 RAPD markerji jih je bilo 9 polimorfnih. Teh 9 markerjev je pomnožilo 79 fragmentov, med katerimi jih je bilo 28 polimorfnih (35\%). Z uporabo 10 od 20 ISSR markerjev so pomnožili 86 fragmentov, od katerih je bilo 35 polimorfnih $(41 \%)$. Indeks markerjev (RAPD = 1,68; ISSR = 1,88 ) in odstotek polimorfnih fragmentov sta pokazala, da so bili ISSR markerji relativno uspešnejši pri ugotavljanju polimorfnosti. Klasterska analiza staršev, ki je temeljila na Jaccardovi genetski podobnosti in na UPGMA metodi je pokazala tri skupine. Liniji obnoviteljev IR68061 in IR5931, z izvorom na Filipinih, sta tvorili jasno ločeno skupino. Rezulti nakazujejo, da bi križance med linijama CMS Neda in Nemat z linijama obnoviteljev IR68061 in IR5931 lahko uporabili kot najboljšo skupino križancev pri uporabi tega načina žlatnenja.

Ključne besede: riž; obnovitelej (restorer); vzdrževalec (maintainer); klasterska analiza; molekularni marker

\section{INTRODUCTION}

Evaluation of genetic diversity in the parental lines is associated with heterosis and performance in hybrid rice production (Wang, 2006). Cytoplasmic male sterility (CMS) systems have been greatly developed in production of hybrid seed and more than $90 \%$ of the rice hybrids belong to wild abortive cytoplasmic source (Yao et al., 1997). Cytoplasmic male sterility is the most influential method for utilization of heterosis. Three different sources of CMS lines (Wild abortive, BaoTai and HongLian) have been characterized (Nematzadeh et al., 2010). Production and commercial exploitation of hybrid rice require wild abortive and nuclear restoration fertility (rf) system.

DNA markers have been utilized for the evaluation of genetic diversity, which could be used to predict heterosis prior to expensive field testing in breeding program (Zhao et al., 1999; Xiao et al., 1996). Among DNA markers, RAPD technique due to simple and low cost process and require no gene sequence information

1 Department of Plant Breeding and Biotechnology, Sari Agricultural Sciences and Natural Resources University, P.O. Box: 578, Sari, Iran, *corresponding author: ghkiani@gmail.com 
is considered to be a suitable approach for identification of cultivar, estimation of genetic diversity and genome mapping and tagging (Wang et al., 1995; Borokova et al., 1995; Raghunathachari et al., 2000). The technique has been used to study genetic diversity among cultivars of several crops like rice (Qian et al., 2001; Rabbani et al., 2008; Rahman et al., 2007; Raghunathachari et al., 2000 ), Barley (Hou et al., 2005) and tomato (Mansour et al., 2010).

In order to unravel some limitation of RAPD marker including dominant inheritance, low reproducibility and uncertainty in locus homology, Inter Simple Sequence Repeat (ISSR) marker can be used to determine genetic diversity. ISSR as a dominant marker involves PCR amplification of given microsatellite repeat which anchored at the $3^{\prime}$ or $5^{\prime}$ end by one to four arbitrary nucleotides using a single sequence repeat (SSR) motifs containing marker (Zietkiewicz et al., 1994). ISSR system has been successfully applied for evaluation of genetic diversity among rice cultivars and other crop plants (Godwin et al., 1997; Joshi et al., 2000; Qian et al., 2001; Wu et al., 2004).

The objective of the present study was to estimate the genetic diversity among 16 parental lines in hybrid rice breeding program using RAPD and ISSR markers.

\section{MATERIALS AND METHODS}

\subsection{Plant materials and DNA extraction}

Sixteen hybrid parental lines including 5 CMS lines, 5 maintainer lines (B-line) and 6 restorer lines (R-line) were used in this study (Table 1). Seeds were obtained from Genetics and Agricultural Biotechnology Institute of Tabarestan, Sari, Iran. Leaf tissues from parental lines were harvested from seedling grown in a greenhouse. Total genomic DNA was extracted following the method of Dellaporta et al. (1983), and its quality and quantity were estimated by spectrophotometry and gel electrophoresis, respectively.

Table1: List of parental lines (CMS, B and R lines) used in this study

\begin{tabular}{lll}
\hline Line name & Type & Origin \\
Nemat & CMS & Iran \\
Nemat & B-line & Iran \\
Neda & CMS & Iran \\
Neda & B-line & Iran \\
Dasht & CMS & Iran \\
Dasht & B-line & Iran \\
Champa & CMS & Iran \\
Champa & B-line & Iran \\
Amol-3 & CMS & Iran \\
Amol-3 & B-line & Iran \\
Sepidrod & R-line & Iran \\
Poya & R-line & Iran \\
Pajohesh & R-line & Iran \\
IR-50 & R-line & The Philippines, IRRI \\
IR68061 & R-line & The Philippines, IRRI \\
IR5931 & R-line & The Philippines, IRRI \\
\hline
\end{tabular}

\subsection{RAPD amplification and assay}

The set of 15 random markers of Operon technologies Inc. were screened. From these, nine markers (Table 2) that produced sharp and scorable bands were selected and used for amplification. PCR aided amplification reaction were carried out in a 12.5 reaction volume containing $1 \mathrm{x}$ buffer PCR (containing $10 \mathrm{mM}$ Tris- $\mathrm{HCl}$ (PH 8.8) and $50 \mathrm{mM} \mathrm{KCl} 0.8 \%$ ), $0.5 \mathrm{mM}$ dNTPs, $5 \mathrm{pM}$ RAPD marker, $2.5 \mathrm{mM} \mathrm{MgCl}_{2}, 30 \mathrm{ng}$ genomic DNA, and 1 Unit of Taq DNA polymerase. The amplification was performed on a MJ Mini, BIO-RAD thermal cycler (USA) for initial step of $4 \mathrm{~min}$ at $94{ }^{\circ} \mathrm{C}$, followed by 40 cycles of $60 \mathrm{~s}$ at $94{ }^{\circ} \mathrm{C}, 60 \mathrm{~s}$ at $35^{\circ} \mathrm{C}, 60 \mathrm{~s}$ at $72{ }^{\circ} \mathrm{C}$ and a final $7 \mathrm{~min}$ extension step at $72{ }^{\circ} \mathrm{C}$. The amplified products were separated by electrophoresis on $1.5 \%$ agarose gels stained with ethidium bromide and visualized by illumination under UV light and photographed. Molecular weights were estimated using a DNA marker 100 bp plus (SM0321, Fermentas). 


\subsection{ISSR amplification and assay}

A total of 20 ISSR markers were screened, in a preliminary experiment. From these, 10 markers were selected for their reproducibility and polymorphism (Table 2). The PCR reaction were performed in the same way as RAPD except for annealing temperature at $50-56{ }^{\circ} \mathrm{C}$. Amplified product were loaded in $2 \%$ agarose gels and were visualized under UV after staining with ethidium bromide. The size of amplified product was estimated using 100 bp plus (SM0321, Fermentas).

\subsection{Data analysis}

Polymorphic bands from dominant markers RAPD and ISSR were scored for the presence (1) or absence (0). Only clear PCR fragments were scored and entered into binary character matrix for further statistical analysis. The capacity of markers to detect polymorphic loci was measured using polymorphic information content (PIC) values and marker index (MI). PIC value was calculated as follows: PIC $=\Sigma\left[2 p_{i}\left(1-p_{i}\right)\right]$, where $p_{i}$ is the frequency of $i$-th allele (Roldàn-Ruiz, 2000; Powell, 1996). The marker index of each marker was estimated using formula; $\mathrm{MI}=\mathrm{PIC} \times$ EMR. Effective multiplex ratio (EMR) is the number of polymorphic loci in the genotype, was calculated as; $\mathrm{EMR}=\mathrm{n} \times \beta$, where $\mathrm{n}$ is the average number of amplified fragments, and $\beta$ was estimated as; $\mathrm{PB} /(\mathrm{PB}+\mathrm{MB})$, where $\mathrm{PB}$ and $\mathrm{MB}$ represent the polymorphic and monomorphic loci, respectively.

The binary data obtained by scoring the RAPD and ISSR were subjected to calculate Jaccard similarity coefficient. Coefficient estimated were used to construct SAHN (Sequential Agglomerative Hierarchical Non Overlapping) clustering using an Unweighted Pair Group Method with Arithmetic Average (UPGMA) in NTSYS software (Rohlf, 1994). In order to determine the best dendrogram analysis to the matrix, cophenetic correlation was performed based on Mantel test (Mantel, 1967).

\section{RESULTS}

\subsection{RAPD analysis}

Among 20 tested arbitrary markers for 16 CMS parental lines, 9 RAPD markers producing clear and polymorphic bands were selected. The number of bands produced by different markers varied from 4 to 12 with an average of 8.87. A total of 79 bands ranging from 200 to 2500 bp were scored, among which 28 bands were polymorphic $(35 \%)$. The number of polymorphic bands varied from 1 to 6 with an average of 3.11 (Table 2). Figure 1 shows an example of polymorphic bands of marker OPA11. PIC varied from 0.29 (OPA12) to 0.45 (OPA03) with average of 0.37 . The marker index, a reflection of marker usefulness, was calculated for each RAPD marker. The average of MI value was 1.68 and ranged from a low of 0.88 (OPH06) to a high of 2.66 (OPH16). 
Table 2: Polymorphism parameter detected with 10 ISSR and 9 RAPD markers in 16 parental lines of hybrid rice

\begin{tabular}{|c|c|c|c|c|c|c|c|c|}
\hline Marker & $\begin{array}{c}\text { marker sequence } \\
\left(5^{\prime}-3^{\prime}\right)\end{array}$ & TB & PB & MB & PPB (\%) & PIC & EMR & MI \\
\hline \multicolumn{9}{|l|}{ ISSR } \\
\hline ISSR2 & $(\mathrm{GA})_{9} \mathrm{C}$ & 10 & 5 & 5 & 50 & 0.33 & 6.35 & 2.11 \\
\hline ISSR7 & $(\mathrm{GA})_{8} \mathrm{C}$ & 15 & 7 & 8 & 47 & 0.37 & 6.80 & 2.54 \\
\hline ISSR8 & $(\mathrm{CT})_{8} \mathrm{G}$ & 7 & 3 & 4 & 43 & 0.18 & 5.70 & 1.05 \\
\hline ISSR12 & $(\mathrm{GA})_{8} \mathrm{~A}$ & 6 & 5 & 1 & 83 & 0.28 & 13.17 & 3.72 \\
\hline ISSR13 & $(\mathrm{TC})_{8} \mathrm{C}$ & 6 & 2 & 4 & 33 & 0.40 & 4.67 & 1.86 \\
\hline ISSR14 & $(\mathrm{TC})_{8} \mathrm{G}$ & 7 & 2 & 5 & 29 & 0.40 & 4.20 & 1.69 \\
\hline ISSR15 & $(\mathrm{AC})_{8} \mathrm{G}$ & 9 & 4 & 5 & 44 & 0.41 & 4.99 & 2.07 \\
\hline ISSR17 & $(\mathrm{AC})_{8} \mathrm{C}$ & 10 & 3 & 7 & 30 & 0.30 & 4.53 & 1.36 \\
\hline ISSR18 & $(\mathrm{ATC})_{6} \mathrm{~T}$ & 8 & 2 & 6 & 25 & 0.25 & 3.84 & 0.95 \\
\hline ISSR19 & $(\mathrm{ATC})_{6} \mathrm{C}$ & 8 & 2 & 6 & 25 & 0.39 & 3.72 & 1.44 \\
\hline \multicolumn{2}{|l|}{ Total } & 86 & 35 & 51 & & & & \\
\hline \multicolumn{2}{|c|}{ Avg./marker } & 8.6 & 3.5 & 5.1 & 40.9 & 0.33 & 5.80 & 1.88 \\
\hline \multicolumn{9}{|l|}{ RAPD } \\
\hline OPA03 & AGTCAGCCAC & 12 & 3 & 9 & 25 & 0.45 & 3.44 & 1.53 \\
\hline OPA11 & CAATCGCCGT & 8 & 2 & 6 & 25 & 0.36 & 3.72 & 1.32 \\
\hline OPA12 & TCGGCGATAG & 9 & 5 & 4 & 56 & 0.29 & 6.05 & 1.76 \\
\hline OPA17 & GACCGCTTGT & 6 & 2 & 4 & 33 & 0.43 & 4.28 & 1.85 \\
\hline OPH03 & AGACGTCCAC & 10 & 4 & 6 & 40 & 0.31 & 5.40 & 1.66 \\
\hline OPH06 & ACGCATCGCA & 6 & 1 & 5 & 17 & 0.38 & 2.33 & 0.88 \\
\hline OPH16 & TCTCAGCTGG & 4 & 2 & 2 & 50 & 0.39 & 6.88 & 2.66 \\
\hline OPN01 & CTCACGTTGG & 14 & 6 & 9 & 43 & 0.37 & 5.95 & 2.18 \\
\hline OPN02 & ACCAGGGGCA & 10 & 3 & 7 & 30 & 0.35 & 3.75 & 1.30 \\
\hline Total & & 79 & 28 & 52 & & & & \\
\hline \multicolumn{2}{|c|}{ Avg./marker } & 8.78 & 3.11 & 5.78 & 35.44 & 0.37 & 4.64 & 1.68 \\
\hline
\end{tabular}

TB: total bands, PB: polymorphic bands, MB: monomorphic bands, PPB (\%): percentage polymorphic bands, PIC: polymorphism information content, EMR: effective multiplex ratio, MI: marker index

\subsection{ISSR analysis}

Among 20 ISSR markers, 10 markers produced clear band profile. A total of 86 scorable bands with the average of 8.6 bands per marker were generated with polymorphism in 35 bands $(41 \%)$. The size of amplified products varied from 200 to $2000 \mathrm{bp}$. The number of polymorphic bands varied from 2 to 7 with the average of 3.5 polymorphic bands per marker (Table 2). ISSR pattern generated by marker ISSR 15 in agarose gel is shown in Figure 1. The mean of PIC value for ISSR markers was 0.33 and varied from 0.18 (ISSR 8) to 0.41 (ISSR 15). The highest and the lowest MI value were 3.72 (ISSR 12) and 0.95 (ISSR 18), respectively with an average of 1.88 .

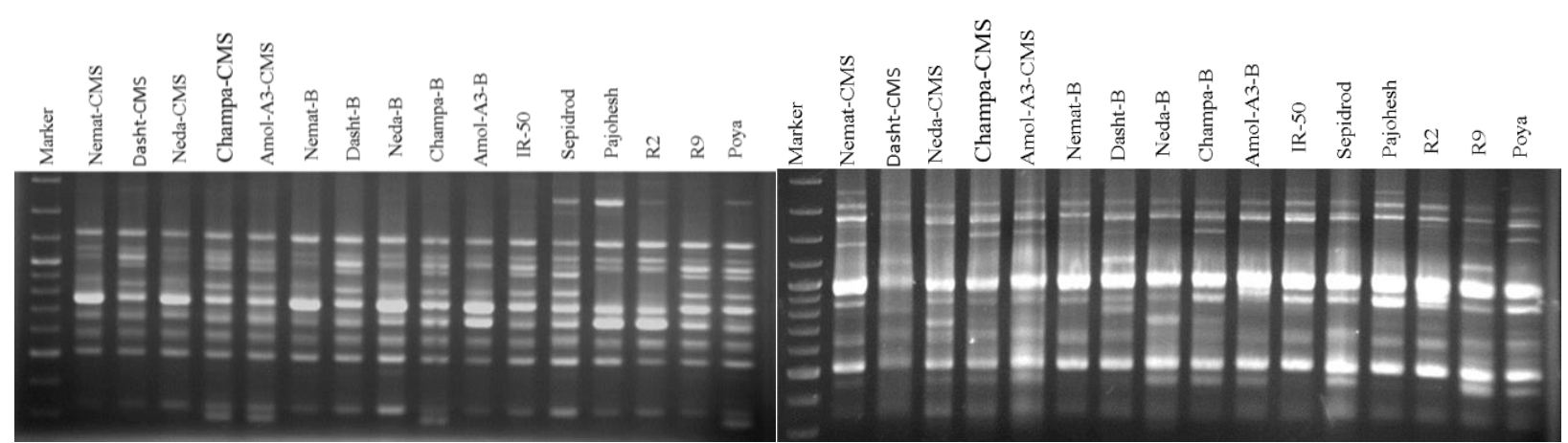

Figure 1: RAPD and ISSR amplification profiles of a 16 parental lines in rice, illustrated by marker OPA11 (left) and ISSR15 (right) 


\subsection{Genetic relationships}

Similarity matrices obtained based on marker data using Jaccard's coefficient pair-wise comparison between genotypes based on RAPD markers revealed that genetic similarity ranged from a maximum of 0.97 (between Neda-CMS and Neda-B) to minimum of 0.75 (between IR68061 and Dasht-CMS) and 0.77 (between Amol3CMS and IR5931), and based on ISSR markers from a maximum of 0.974 (between Champa-B and Amol3-B) to minimum of 0.76 (between IR5931 and Nemat-CMS) and 0.77 (between IR5931 and NedaCMS).

Maximum genetic similarity of combination similarity coefficient was observed between Champa-B and AmolA3-B (0.965), and minimum was observed between Dasht-CMS and IR5931 (0.786). Average of similarity index in RAPD and ISSR markers were 0.866 and 0.869 , respectively.

\subsection{Cluster analysis}

The cluster analysis based on Jaccard's similarity coefficient through RAPD and ISSR data generated similar dendrogram topologies with some differences. The dendrogram based on RAPD analysis presented in Fig. 2. Cluster analysis based on RAPD data grouped 16 lines to 3 major groups. Group I consisted of four genotypes namely Nemat-CMS, Nemat-B, IR50 and Poya. The majority of the genotypes placed in group II, while two the Philippines' varieties formed a distinct cluster of III.

Cluster analysis based on ISSR data also formed three groups (Fig. 3). Nemat-B and Neda-B with their counterparts (Nemat-CMS and Neda-CMS) were put in cluster I. Cluster II consisted of Dasht-CMS, Dasht-B, Champa-CMS, Pajohesh, Amol3-B, Champa-B, IR50, Spidrod, Amol3-CMS and Poya. The Philippines' varieties IR68061 and IR5931 formed a distinct group (cluster III).

Matrices correlation coefficient were obtained using Mantel test, to compare the two Jaccard's similarity matrices and the correlation value, was 0.61. The test indicated that cluster constructed based on RAPD and ISSR markers were approximately conserved (moderate degree of correlation).

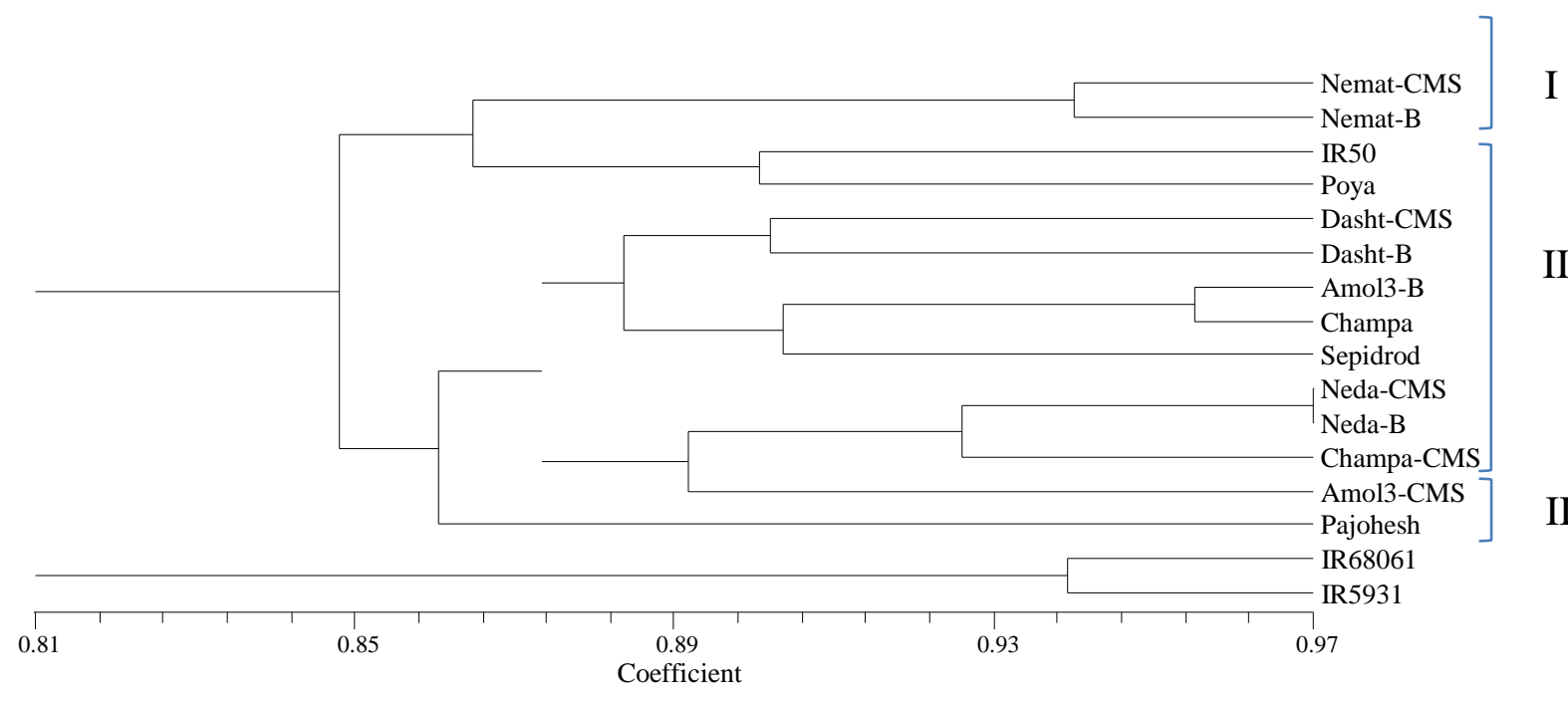

Figure 2: Cluster of 16 parental lines based on RAPD markers using the UPGMA methods 


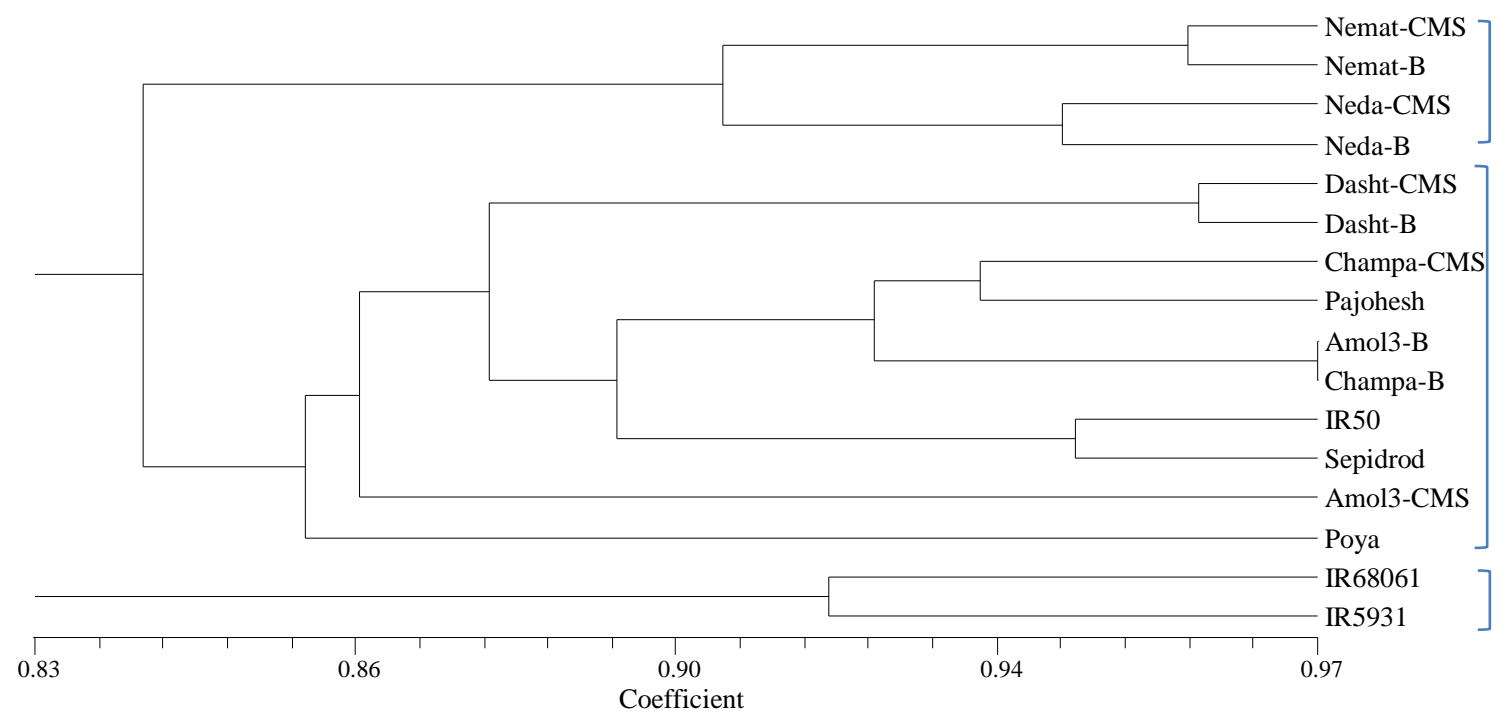

Figure 3: Cluster of 16 parental lines based on ISSR markers using the UPGMA methods

\section{DISCUSSION}

Prerequisite of performance and heterosis of hybrids is maximum diversity in parental lines, hence the grouping of parental lines based on genetic divergence is essential for breeders. In order to resolve the problems associated with morphological and biochemical markers, molecular markers considered as alternative tools for diversity investigations. Several markers such as SSR, AFLP, and RFLP have been used to determine genetic diversity between parental lines in rice (Subudhi et al., 1998; Zhang et al., 1997; Xu et al., 2002). In present investigation, RAPD and ISSR markers were employed to detect the genetic relationship between parental lines of hybrid rice (CMS, B and $\mathrm{R}$ lines).

The proportion of polymorphic bands revealed by ISSR (41\%) and RAPD (35\%), and mean MI for each of the markers (1.88 for ISSR and 1.68 for RAPD) suggested that ISSR marker systems have more discriminating power than RAPD markers in genetic diversity detection. Mean PIC for each of the markers was approximately similar ( 0.33 for ISSR and 0.37 for RAPD). Qian et al. (2001) also reported similar results in assess of genetic diversity in wild rice (Oryza granulata Nees \& Arn. ex G.Watt.) population. Also, Ravi et al, (2005) reported SSR were more polymorphic than RAPD markers. A number of research groups reported that RAPD markers are more polymorphic than ISSR markers (Muthusamy et al., 2008; Kumar et al., 2014), which might be because of different frequency of microsatellite rich-region in various organisms and different amplification of genomic regions by each of marker system (Xu et al., 2002).
According to cluster topologies, the CMS lines were grouped in minimal distance from their maintainer lines such as Neda-CMS-Neda-B, Nemat-CMS-Nemat-B and Dasht-CMS-Dasht-B both in Fig 2 and Fig. 3, which suggested that nuclear genes of maintainer lines were similar with corresponding CMS lines. However, Champa-CMS and Amol3-CMS were not placed in minimal distances with their counterparts, Champa-B and Amol3-B. The reason behind this observation might be due to some degrees of contamination in multiplication process of these two CMS lines. This study involved thirteen hybrid parental lines from Iran along with three $\mathrm{R}$ lines from the Philippines (IR50, IR68061 and IR5931). IR50 had similarity with the genotypes of cluster I and cluster II using RAPD and ISSR markers, respectively. While the two Philippines lines, IR68061 and IR5931, formed a distinct group either in dendrograms using RAPD and ISSR data (Fig. 2 and Fig. 3).

The majority of lines were distributed into group I and II, however, R lines were grouped into distinct subgroup in all clusters. Restorer lines IR68061 and IR5931 formed distinct group III revealing highest genetic distance with other CMS and B lines. Genetic distance between restorer parents with IRRI origin and other Iranian lines suggested that these genotypes could be used to attain heterosis in further crosses. In group I, Neda and Nemat (CMS and maintainer lines) were tightly grouped together in molecular clustering studied with ISSR (Figure 3) which could be due to the existence of common pedigree in both cultivars 
(Nematzadeh et al., 1997; 2001). Similar results were observed in assessing genetic variation using RAPD and SSR markers for predicting performance and heterosis of indica $\times$ japonica hybrids (Xiao et al., 1996).

Results obtained from this study suggested that, i: ISSR is superior to RAPD in assessing genetic distance and relationship between CMS and restorer lines. ii: based on genetic relationship, one can expect that the cross of CMS lines in group I (Neda and Nemat) with restorer lines in group III (IR68061 and IR5931), with the highest genetic distance, can develop the best heterotic groups for accessing strong heterosis. Therefore, hybrids of Neda-CMS $\times$ IR68061, Neda-CMS $\times$ IR5931, Nemat-CMS $\times$ IR68061 and Nemat-CMS $\times$ IR5931 can be suggested for experimental hybrid seed production. The heterotic group detection in parental lines with the aid of RAPD and ISSR markers could be effective tools to prevent the crosses between unrelated heterotic groups, thus reducing costs in hybrid seed production.

\section{ACKNOWLEDGEMENT}

This project was supported financially by Sari Agricultural Sciences and Natural Resources University.
The Authors thank to Ghorban Ali Nematzadeh for providing seed materials.

\section{REFERENCES}

Dellaporta, S. L., Wood, J. and \& Hicks, J. B. (1983). A Plant DNA Mini-preparation: version II. Plant Molecular Biology Reporter, 1, 19-21. doi:10.1007/BF02712670

Godwin, I. D., Aitken, E. A. and \& Smith, L. W. (1997). Application of inter simple sequence repeat (ISSR) markers to plant genetics. Electrophoresis, 18, 1524-1528. doi:10.1002/elps.1150180906

Hou, Y. C., Yan, Z. H., Wei, Y. M. and \& Zheng, Y. L. (2005). Genetic diversity in barley from west China based on RAPD and ISSR analysis. Barley Genetics Newsletter, 35, 9-22.

Joshi, S., Gupta, V., Aggarwal, R., Ranjekar, P. \& Brar, D. (2000). Genetic diversity and phylogenetic relationship as revealed by inter simple sequence repeat (ISSR) polymorphism in the genus Oryza. Theoretical and Applied Genetics, 100, 1311-1320. doi:10.1007/s001220051440

Kumar, A., Mishra, P., Singh, S. C. and \& Sundaresan, V. (2014). Efficiency of ISSR and RAPD markers in genetic divergence analysis and conservation management of Justicia adhatoda L., a medicinal plant. Plant Systematics and Evolution, 1-12. doi:10.1007/s00606-013-0970-z

Mansour, A., Teixeira Da Silva, J., Edris, S. and \& Younis, R.A. (2010). Comparative assessment of genetic diversity in tomato cultivars using IRAP, ISSR and RAPD molecular markers. Focus on Tree Genetics and Genomics. Genes, Genomes and Genomics, 4, 41-47.

Mantel N. (1967). The detection of disease clustering and a generalized regression approach. Cancer Research, 27 , 209-220.
Muthusamy, S., Kanagarajan, S. and \& Ponnusamy, S. (2008). Efficiency of RAPD and ISSR markers system in accessing genetic variation of rice bean (Vigna umbellata) landraces. Electronic Journal of Biotechnology, 11, 32-41. doi:10.2225/vol11issue3-fulltext-8

Nematzadeh, G., Arefi, H., Amani, R. and \& Mani, R. (1997). Introduction of high yield variety "Nemat" with good quality. Agricultural science journal, 28, 79-86 (Persian).

Nematzadeh, G., Arefi, H., Khonacdar, Y. and \& Nasiri, Z. 2001. "Neda" a high yielding rice cultivar with suitable physicochemical characteristics. Seed and Plant, 24, 107-115 (Persian).

Nematzadeh, Gh. and \& Kiani, G. (2010). Genetic analysis of fertility restoration genes for WA type cytoplasmic male sterility in Iranian restorer rice line DN-33-18. African Journal of Biotechnology, 9, 6273-6277.

Powell, W., Morgante, M., Andre, C., Hanafey, M., Vogel, J., Tingey, S. and \& Rafalski, A. (1996). The comparison of RFLP, RAPD, AFLP and SSR (microsatellite) markers for germplasm analysis. Molecular breeding, 2, 225-238. doi:10.1007/BF00564200

Qian, W., Ge, S. and \& Hong, D. -Y. (2001). Genetic variation within and among populations of a wild rice Oryza granulata from China detected by RAPD and ISSR markers. Theoretical and Applied Genetics, $\quad 102, \quad 440-449$. doi:10.1007/s001220051665

Rabbani, M. A., Pervaiz, Z. H., and \& Masood, M. S. (2008). Genetic diversity analysis of traditional and 
improved cultivars of Pakistani rice (Oryza sativa L.) using RAPD markers. Electronic Journal of Biotechnology, 11, 52-61. doi:10.2225/vol11issue 3-fulltext-3

Raghunathachari, P., Khanna, V. K., Singh, U. S., \& Singh, N. K. (2000). RAPD analysis of genetic variability in Indian scented rice germplasm (Oryza sativa L.). Current Science, 79, 994-998.

Raghunathachari, P.; Khanna, V.K.; Singh, U.S. and Singh, N.K. 2000 RAPD analysis of genetic variability in Indian scented rice germplasm (Oryza sativa L.). Current Science, 7, 994-998.

Rahman, S. N., Islam, M. S., Alam, M. S. and \& Nasiruddin, K. M. (2007). Genetic polymorphism in rice (Oryza sativa L.) through RAPD analysis. Indian Journal of Biotechnology, 6, 224.

Rohlf, F.J. (1994). NTSYS-PC: Numerical Taxonomy and Multivariate Analysis System Version 2.2. State University of New York, Stony Brook N.Y.

Subudhi, P., Nandi, S., Casal, C., Virmani, S. and \& Huang, N. (1998). Classification of rice germplasm: III. High-resolution fingerprinting of cytoplasmic genetic male-sterile (CMS) lines with AFLP. Theoretical and applied genetics, 96, 941-949. doi:10.1007/s001220050824

Wang, B., Xu, W., Wang, J., Wu, W., Zheng, H., Yang, Z., Ray, J. and \& Nguyen, H. (1995). Tagging and mapping the thermo-sensitive genic male-sterile gene in rice (Oryza sativa L.) with molecular markers. Theoretical and Applied Genetics, 91, 1111-1114. doi:10.1007/BF00223928

Wang, S. and \& Lu, Z. (2006). Genetic diversity among parental lines of Indica hybrid rice (Oryza sativa L.) in China based on coefficient of parentage. Plant Breeding, 125, 606-612. doi:10.1111/j.14390523.2006.01268.x

Wu, C. J., Cheng, Z. Q., Huang, X. Q., Yin, S. H., Cao, K. M. and \& Sun, C. R. (2004). Genetic diversity among and within populations of Oryza granulata from Yunnan of China revealed by RAPD and ISSR markers: implications for conservation of the endangered species. Plant Science, 167, 35-42. doi:10.1016/j.plantsci.2004.02.022

Xiao, J., Li, J., Yuan, L., Mc Couch, S. and \& Tanksley, S. (1996). Genetic diversity and its relationship to hybrid performance and heterosis in rice as revealed by PCR-based markers. Theoretical and Applied Genetics, 92, 637-643. doi:10.1007/BF00226083

Xu, W., Virmani, S. S., Hernandez, J. E., Sebastian, L. S., Redoña, E. D. and \& Li, Z. (2002). Genetic diversity in the parental lines and heterosis of the tropical rice hybrids. Euphytica, 127, 139-148. doi:10.1023/A:1019960625003

Yao, F., Y., Xu, C., G., Yu, S, .B., Li, J, .X., Gao, Y., J., Li, X, .H. and \& Zhang, Q, .F. (1997). Mapping and genetic analysis of two fertility restorer loci in the wild-abortive cytoplasmic male sterility system of rice (Oryza sativa L.). Euphytica, 98, 183-187. doi:10.1023/A:1003165116059

Zhang, Q., Liu, K., Yang, G., Maroof, M. S., Xu, C. and \& Zhou, Z. (1997). Molecular marker diversity and hybrid sterility in indica-japonica rice crosses. Theoretical and Applied Genetics, 95, 112-118. doi:10.1007/s001220050538

Zhao, M., Li, X., Yang, J., Xu, C., Hu, R., Liu, D. and \& Zhang, Q. (1999). Relationship between molecular marker heterozygosity and hybrid performance in intra-and inter-subspecific crosses of rice. Plant Breeding, 118, 139-144. doi:10.1046/j.1439-0523.1999.118002139.x

Zietkiewicz, E., Rafalski, A. and \& Labuda, D. (1994). Genome fingerprinting by simple sequence repeat (SSR)-anchored polymerase chain reaction amplification. Genomics, 20, 176-183. doi:10.1006/geno.1994.1151 